\title{
Desiccation limits recruitment in the pleometrotic desert seed-harvester ant Veromessor pergandei
}

\author{
Robert A. Johnson
}

School of Life Sciences, Arizona State University, Tempe, AZ, USA

\section{Correspondence}

Robert A. Johnson, School of Life Sciences, Arizona State University, Tempe, AZ 852874501 USA.

Email: Robert.Johnson4@asu.edu

\section{Funding information}

The author funded this project.

[Correction Statement: Correction added on 11 December 2020 after first online publication: The supporting information file has been updated in this version.]

\begin{abstract}
The desert harvester ant Veromessor pergandei displays geographic variation in colony founding with queens initiating nests singly (haplometrosis) or in groups (pleometrosis). The transition from haplo- to pleometrotic founding is associated with lower rainfall. Numerous hypotheses have been proposed to explain the evolution of cooperative founding in this species, but the ultimate explanation remains unanswered. In laboratory experiments, water level was positively associated with survival, condition, and brood production by single queens. Queen survival also was positively influenced by water level and queen number in a two-factor experiment. Water level also was a significant effect for three measures of queen condition, but queen number was not significant for any measure. Foundress queens excavated after two weeks of desiccating conditions were dehydrated compared to alate queens captured from their natal colony, indicating that desiccation can be a source of queen mortality. Long-term monitoring in central Arizona, USA, documented that recruitment only occurred in four of 20 years. A discriminant analysis using rainfall as a predictor of recruitment correctly predicted recruitment in 17 of 20 years for total rainfall from January to June (the period for mating flights and establishment) and in 19 of 20 years for early plus late rainfall (January-March and April-June, respectively), often with a posterior probability $>0.90$. Moreover, recruitment occurred only in years in which both early and late rainfall exceeded the long-term mean. This result also was supported by the discriminant analysis predicting no recruitment when long-term mean early and late rainfall were included as ungrouped periods. These data suggest that pleometrosis in V. pergandei evolved to enhance colony survival in areas with harsh abiotic (desiccating) conditions, facilitating colonization of habitats in which solitary queens could not establish even in wet years. This favorable-year hypothesis supports enhanced worker production as the primary advantage of pleometrosis.
\end{abstract}

\section{KEYWORDS}

cooperation/grouping, environmental harshness, foundress ants, moisture, seed-harvester ants, Sonoran Desert

This is an open access article under the terms of the Creative Commons Attribution License, which permits use, distribution and reproduction in any medium, 


\section{1 | INTRODUCTION}

Water is the primary factor controlling ecological processes in deserts, including demographic patterns, distribution patterns, physiological processes, response thresholds, and life history attributes of a species (Ehleringer \& Sandquist, 2018; Johnson, 2006; Jordan \& Nobel, 1979; Nobel, 1988; Noy-Meir, 1973; Reynolds et al., 2004; Riddell et al., 2019). These processes are affected by amount of rainfall as well as by high interannual variability and unpredictability in rainfall (MacMahon \& Wagner, 1985) as evidenced by changes in occurrence and microdistribution of species following decadal changes in rainfall (Ehleringer \& Sandquist, 2018; Iknayan $\&$ Beissinger, 2018). Recruitment of new individuals in desert habitats also is intimately linked to rainfall for many species (Gibson \& Nobel, 1986; Nobel, 1988).

Moisture is one of the most limiting abiotic factors for invertebrates because their small size and high surface-to-volume ratios make them prone to desiccation (Hadley, 1994; Harrison et al., 2012). Evidence of such limitation most frequently involves studies that correlate physiological tolerances of organisms with their microdistribution pattern (Bujan et al., 2016; Chown \& Klok, 2003; Hood \& Tschinkel, 1990; Talbot, 1934). Water loss rate, dehydration tolerance, and body size combine to determine physiological tolerance of organisms to desiccation. In arid habitats, increased body size appears to be one of the more important characters related to increasing desiccation resistance (Chown \& Klok, 2003; Le Lagadec et al., 1998; Scholtz \& Caveney, 1988; Tejeda et al., 2016). Insects and other arthropods can also use behaviors such as grouping to increase their effective body size, thus resulting in physiological benefits that include decreased water loss and increased longevity (Bong et al., 2018; Broly et al., 2014; Klok \& Chown, 1999). As a result, grouping has potential to allow organisms to inhabit more physiologically harsh areas than possible by solitary individuals (Avilés, 1999; Liu et al., 2020).

Colony founding is the most critical and vulnerable stage in the life of ant colonies, and this is also the stage at which desiccation would have its strongest effect on limiting recruitment of new colonies (Hölldobler \& Wilson, 1990; Johnson, 1998). Studies that directly assess the effect of moisture on founding queens demonstrate a positive correlation between moisture and queen survival, queen condition, and number of first brood workers (Cahan, 1999; Johnson, 1998). Body size also affects desiccation tolerance and microhabitat occurrence for two other desert ant species in the genus Pogonomyrmex; the larger queens of $P$. rugosus are more desiccation tolerant than those of $P$. barbatus, which correlates with $P$. rugosus colonies occurring in more xeric microhabitats than those inhabited by P. barbatus (Johnson, 2000a). In some ant species, multiple unrelated queens group during colony founding (pleometrosis) (Bernasconi \& Strassman, 1999), and this behavior has potential to enhance queen survival and the establishment of new colonies, that is, recruitment, because of physiological benefits similar to those observed for other insects (see above), but data are lacking (but see Cahan, 1999).
The proximate benefits of pleometrosis include at least one of the following: (a) earlier emergence of first workers, (b) increased number of workers, (c) decreased mass loss by queens, (d) increased defense against workers from neighboring mature colonies, and (e) disease control (Bartz \& Hölldobler, 1982; Jerome et al., 1998; Pull \& Cremer, 2017; Rissing \& Pollock, 1987; Sommer \& Hölldobler, 1995; Tschinkel \& Howard, 1983). Pleometrosis can also enhance the survival rate of queens, though the mechanism causing this increase is unclear (Johnson, 2004; Waloff, 1957). At the ultimate level, for pleometrosis to evolve and persist requires that survival probability for a queen in an association of $n$ queens is more than $n$ times greater than that of a solitary queen (Adams \& Tschinkel, 1995). Overall, pleometrosis is viewed as advantageous when intercolony competition is intense, both by adult and incipient colonies (for a review see Bernasconi \& Strassman, 1999), or under harsh abiotic conditions (Cahan, 2001b; Pfennig, 1995). Harsh abiotic conditions have been suggested to favor pleometrosis because of its potential to confer greater desiccation resistance for groups compared to single queens (Cahan, 2001b). Notably, these two conditions (intense intercolony competition and harsh abiotic environment) correspond to different levels of survival; high levels of founding queen survival support the intercolony competition hypothesis, while low queen survival supports the hypothesis that harsh abiotic conditions limit colony recruitment.

Several studies document that recruitment of new colonies is rare in the desert seed-harvester ant Veromessor pergandei (Mayr) (formerly Messor pergandei) (Pfennig, 1995; Raczkowski, 2003; Ryti $\&$ Case, 1988). The several mostly proximate hypotheses presented to explain the evolution of pleometrosis in this species include: (a) intraspecific competition in the form of higher success at brood raiding (Rissing \& Pollock, 1987), (b) inter-colony interference competition (Pfennig, 1995), (c) the need to quickly find a nest to avoid desiccation and predators (Pfennig, 1995), (d) enhanced foraging success leading to increased colony survival and growth (Brown, 2000), and (e) enhanced water balance of grouped compared to solitary queens, especially under xeric conditions (Cahan, 1999; Raczkowski, 2003).

Two field studies have examined pleometrosis in V. pergandei with contradictory results. Pfennig (1995) found no difference in survival or longevity for one versus two queen colonies, leading him to suggest that interference competition among incipient colonies does not select for pleometrosis. Alternatively, at the same site Raczkowski (2003) found that both survival and longevity were higher for three queen compared to one queen colonies, and that distance to a mature colony did not affect longevity.

This study tests hypotheses related to founding queen survival and recruitment of new colonies in a pleometrotic population of V. pergandei. I used laboratory experiments, field data, and longterm census data to test the hypothesis that insufficient moisture limits survival of founding queens and recruitment of new colonies. I also tested the desiccation resistance hypothesis using a two-factor (queen number $\times$ moisture level) laboratory experiment to determine the relative importance of these two effects on queen survival and condition. This experiment also tested two 
predictions of the desiccation resistance hypothesis: (a) grouping enhances queen survival to a higher degree under desiccating compared to mesic conditions, and (b) a more positive water balance results for grouped than for solitary queens under desiccating conditions.

\section{2 | METHODS}

\section{1 | Study species}

Veromessorpergandei (subfamily myrmicinae) is a common soil nesting, seed-harvester ant that inhabits the Sonoran, Colorado, and Mojave Deserts, typically in sandy soils at elevations $<900 \mathrm{~m}-$ areas that collectively encompass the hottest, most arid portions of North America (Creighton, 1950, 1953; Johnson, 1992, 2000c; Tevis, 1958). Mature colonies contain $>35,000$ foragers that form conspicuous foraging trails that extend $>35 \mathrm{~m}$ from the nest (Plowes et al., 2012).

The colony cycle of $V$. pergandei begins with mating flights, which usually occur from mid-February to late March (Cahan, 2001b; Ode \& Rissing, 2002; Pollock \& Rissing, 1985). A moderate number of sexuals fly from nests on each flight day, with sexuals flying $30-50 \mathrm{~m}$ above ground to mate in the air (i.e., non-lek mating); pairs sometimes fall to the ground in copulo. Founding queens initiate nests throughout a site, though they are most common in open areas that lack vegetation (Rissing \& Pollock, 1989).

Queen founding behavior varies across the geographic range: single queens (haplometrosis) initiate nests in western portions of the range, that is, southwestern Arizona and southern California, whereas multiple, unrelated queens (pleometrosis) initiate nests in eastern and northwestern portions of the range, that is, central and western Arizona, southeastern California, and southern Nevada (Hagen et al., 1988; Helms Cahan \& Helms, 2012; Johnson, 2000b; Pollock \& Rissing, 1985; Rissing et al., 2000; Ryti, 1988). In areas of pleometrosis, queens accumulate in founding nests during the mating season, but additional queens are never accepted in the colony after the first workers emerge. Pleometrotic queens cooperate to produce the first brood of workers, with worker production being a linear function of queen number (Rissing \& Pollock, 1986, 1991). Additional variation occurs in pleometrotic parts of the range because colonies reduce to one queen (monogyny) after worker emergence in eastern areas, whereas multiple queens persist in mature colonies (primary polygyny) in northwestern portions of the range (Helms \& Helms Cahan, 2012; Rissing \& Pollock, 1986 1987). In southeastern California, the shift from haplometrosis to pleometrosis occurs across a narrow transition zone with the shift to pleometrosis correlating with reduced precipitation, decreased vegetative biomass, and lower colony density (Cahan, 2001a, 2001b; Cahan et al., 1998). Surviving colonies then enter their growth phase and probably start producing reproductive sexuals after 3-4 years; colonies likely live 10-20 + years (Tevis, 1958; Wheeler \& Rissing, 1975)

\section{2 | Study site}

I studied V. pergandei at a site that extended from approximately $2 \mathrm{~km}$ south to $3 \mathrm{~km}$ southwest of Signal Peak, Pinal County, Arizona $\left(32^{\circ} 56^{\prime}-57^{\prime} \mathrm{N}, 111^{\circ} 40^{\prime}-42^{\prime} \mathrm{W}\right.$; elevation 435-450 m). Habitat of the area was typical Sonoran Desert and consisted of a creosote bush (Larrea tridentata)-triangle leaf bursage (Ambrosia deltoidea) association with scattered ironwood (Olneya tesota) and foothill palo verde (Parkinsonia microphyllum). Substrate consisted of moderately coarse sand (see Johnson, 1992). Other common ants at the site included Pogonomyrmex rugosus, Pogonomyrmex pima, Pheidole xerophila, Dorymyrmex insanus, and Solenopsis xyloni. Veromessor pergandei queens initiate nests pleometrotically at this site, but queens reduce to monogyny following emergence of the first workers (Pfennig, 1995; Rissing \& Pollock, 1986, 1987).

\section{3 | Laboratory experiments on moisture level and queen number}

I conducted two laboratory experiments to examine the effect of moisture on queen survival and brood production. The first experiment examined the effect of moisture level on survival, condition (wet mass, water content, dry mass), and brood production for single queens. The second experiment used a two-factor design to examine the effects of queen number and moisture level on queen survival and condition.

Both experiments used eight ounce $(0.24 \mathrm{~L})$ glass bottles that contained $325 \mathrm{~g}$ of soil and $45 \mathrm{mls}$ of water. Soil was collected at the study site in areas occupied by $V$. pergandei, passed through a $2 \mathrm{~mm}$ sieve, mixed into a composite sample, weighed, and placed into bottles. The moisture treatments involved adding water to bottles every 10 days starting on day 20; the first experiment used four moisture levels $-0,5,10$, and $15 \mathrm{mls}$ of water; the second experiment used 0,5 , and $10 \mathrm{mls}$ of water. Founding queens were excavated from their incipient nests, placed in closed containers with moist paper towels for several hours, weighed, and then placed in bottles. Bottles in the first experiment contained one queen ( $n=270 ; 100$ in 0 mls water, 70 in 5 mls water, 50 in 10 mls water, 50 in $15 \mathrm{mls}$ water). Bottles in the second experiment contained one, three, or five queens ( $n=900$ queens in 460 bottles; 120 queens per queen treatment in 0 mls water, 120 queens per queen treatment in $5 \mathrm{mls}$ water, 60 queens per queen treatment in $10 \mathrm{mls}$ water); queens in the second experiment were uniquely marked with Tamiya paint (Aliso Viejo, California) prior to weighing. Both experiments were set up so that initial wet mass of queens was similar across treatments (experiment 1: one-way ANOVA, $F_{3,266}=0.30, p>0.80$; experiment 2: $F_{8,891}=0.77, p>0.60$ ), thus minimizing effects caused by mass. Bottles were sealed for 1-2 days to allow queens to excavate their nest. I then removed and replaced dead queens that were visible on the soil surface, and lids were replaced with a plastic petri dish that contained several holes. Bottles were maintained in a darkened room at $20-25^{\circ} \mathrm{C}$. 
In the first experiment, bottles were emptied after 92 days, which was approximately 1-2 weeks after workers began to appear on the soil surface. Bottles were emptied after 66 days in the second experiment; this time interval was chosen so as to end the experiment prior to worker emergence and queen reduction. Queen status (live or dead) was determined in both experiments, and brood (larvae, pupae, workers) were counted in the first experiment. Live queens were weighed, dried for $>72 \mathrm{hr}$ at $50-55^{\circ} \mathrm{C}$, and then reweighed.

In both experiments, queen survival was analyzed by a logistic regression that used a binomial distribution and logit link function (PROC GENMOD in SAS 6.12) (SAS Institute, 1997). Queen status (live or dead) was the dependent variable and moisture level was the independent variable in the first experiment; moisture level and queen number were the independent variables in the second experiment. The model uniquely coded each treatment cell in both experiments, which resulted in comparing survival rates across all treatment cells simultaneously. Significance levels were based on the Wald Chi-square statistic.

In the first experiment, queen wet mass, water mass, dry mass, and number of brood were analyzed across moisture levels using a one-way ANOVA. In the second experiment, I included data for only bottles in which $\geq 2$ queens and $\geq 4$ queens survived in the three and five queen bottles, respectively. Wet mass, water mass, and dry mass were each analyzed using a two-way ANOVA followed by a univariate Duncan's multiple range post hoc test for the two main effects. This was followed by a one-way ANOVA with Duncan's multiple range test across all cells. Data were transformed, as necessary, to meet the assumptions of ANOVA.

\subsection{Growth of single queen colonies in the laboratory}

I determined number of workers and brood that single queens produced by the end of the founding stage as well as over their first several months given that more workers hasten increasing the size and depth of the nest so as to escape harsh temperature and moisture conditions near the soil surface. I determined number of minim workers produced by the end of the founding stage by placing single queens in glass "ants farms" $(16 \times 10 \times 1.5 \mathrm{~cm})$ filled with soil, which facilitated observing nests and counting minim workers. I placed additional single queens in $12 \mathrm{oz}$ bottles $(0.35 \mathrm{~L})$ filled with sieved soil that had been thoroughly moistened; the bottles were then sealed with a screw-top lid and placed in an incubator at $30 \pm 1.0^{\circ} \mathrm{C}$. Colonies were given ad libitum Kentucky bluegrass seeds (Poa pratensis) after the first workers emerged. Bottles were emptied after 90 days, and workers, pupae, and larvae were counted.

\subsection{Desiccation of founding queens in the field}

I also examined desiccation as a source of mortality for founding queens by comparing water status for alate queens in their natal nests to founding queens excavated from their incipient nests. In 1999, V. pergandei had its first mating flight on 19 February, and additional flights were absent to very weak until 1 March, when sexuals exited nests for a flight that was largely aborted. On both dates, I collected 10 unmated alate (winged) queens from outside natal nests at each of three colonies. Founding queens were excavated on $3 \mathrm{March}$; these queens had likely initiated nests about 2 weeks earlier given the absence of flight activity from 19 February to 3 March. Each alate/founding queen was placed in an Eppendorf tube, placed on ice, and weighed within 15 min of capture on a Mettler AE 163 balance attached to a power inverter. Individuals were then returned to the laboratory, placed in an oven at $50-55^{\circ} \mathrm{C}$ for $>72 \mathrm{hr}$, and reweighed.

I assessed water status of field-weighed alate queens by comparing their water content to that of hydrated alate queens. Determining water content of hydrated queens involved collecting 10 alate queens from each of eight colonies in 1993 and 1994 (four colonies from the study site and four colonies from $5 \mathrm{~km}$ east of the White Tank Mountains, Maricopa County, AZ $\left[33^{\circ} 36^{\prime} \mathrm{N}\right.$, $\left.\left.112^{\circ} 28^{\prime} \mathrm{W} ; 400 \mathrm{~m}\right]\right)$. Individuals were placed in an enclosed container with a moistened paper towel and allowed to hydrate for several hours; they were then weighed, dried at $50-55^{\circ} \mathrm{C}$ for $>72 \mathrm{hr}$, and reweighed. Wet mass, water mass, and dry mass were compared across the four groups of queens (alates collected on each of two dates, hydrated alates, founding queens) using a one-way ANOVA followed by Duncan's multiple range test (SPSS, 1990).

I also quantified dehydration tolerance of alate queens so as to determine amount of water loss at which mortality occurs in the field. Dehydration tolerance was determined using hydrated alate queens (3-4 individuals from each of 10 colonies), which were weighed, and individuals were then placed in $20 \times 7 \mathrm{~mm}$ chambers made of rigid plastic tubes sealed on both ends with push-fit caps of stainless steel screen (Johnson, 2000d; Johnson et al., 2011). Chambers were connected in tandem with pliable plastic tubing, with up to 10 chambers per column. Individuals were placed at $15-20^{\circ} \mathrm{C}$, which mimicked soil temperatures that queens experience during early phases of nest founding. Air desiccated by Drierite was forced through columns at a rate of $100-150 \mathrm{mls} / \mathrm{min}$, as controlled by a needle valve and rotameter. Individuals were examined every few hours; those that could not right themselves were weighed, dried for $>72 \mathrm{hr}$ at $50-55^{\circ} \mathrm{C}$, and reweighed. All mass loss over this period was assumed to result from water loss. Dehydration tolerance was calculated using the formula DT $=100 \times(L / H)$, where DT is the percent body water lost at the time an individual could not right herself, $L$ is water mass (mg) lost at the time of losing locomotor ability, and $H$ is water mass ( $\mathrm{mg}$ ) in a hydrated state. These data were used to assess hydric condition of founding queens in the field.

\subsection{Recruitment in the field}

Six 1.25 ha $(112 \times 112 \mathrm{~m})$ plots were established in 1991 about $2.5 \mathrm{~km}$ south of Signal Peak (see above). Plots were censused each 
year between late August and late November, 1991-2001. Censuses were conducted by walking systematic $5 \mathrm{~m}$ wide transects throughout each plot, noting colonies of $V$. pergandei that had been initiated earlier that year based on their small nests and absence of workers larger than a minim. These plots were subsequently developed and could no longer be censused. In 2005 and 2012-2019, I surveyed for new colonies of $V$. pergandei by walking through the general area over several days.

Rainfall was examined as a factor limiting recruitment by V. pergandei over the 20 surveyed years. The annual rainfall pattern is bimodal in this part of the Sonoran Desert with similar amounts falling in winter and summer (Reynolds et al., 2004). The 1-2 month period prior to mating flights up to the beginning of summer rains, that is, January through June, is viewed as the most critical interval for rainfall to affect survival for founding queens of $V$. pergandei. Moreover, rainfall decreases dramatically near the end of March, and the three spring months-April, May, and June-are the three driest months of the year (MacMahon \& Wagner, 1985; Reynolds et al., 2004). Summer rains typically begin in early to mid-July. This pattern is exemplified by the Casa Grande weather station, which is the station nearest ( $\approx 6.5 \mathrm{~km} \mathrm{SW})$ to the field site. From January through June, 1981-2009, rainfall at this station averaged $80.77 \mathrm{~mm}$, with $64.01 \mathrm{~mm}$ (79.2\%) falling from January-March and $16.76 \mathrm{~mm}$ (20.8\%) from April-June (see http://www.wrcc.dri.edu/cgi-bin/ cliMAIN.pl?az1306).

Daily rainfall data were obtained from the National Oceanic and Atmospheric Administration, National Climatic Data Center (https://www.ncdc.noaa.gov/cdo-web/datasets/GHCND/stati ons/GHCND:USC00021306/detail) for the Casa Grande weather station, which is the station nearest to the study site (see above), or from the Casa Grande National Monument station ( $\approx 13 \mathrm{~km} \mathrm{NE}$ of the site) when data were missing from the Casa Grande station. The Casa Grande weather station ceased operating in 2009. In subsequent years, nearby stations operated for short periods. I used the Casa Grande 4.2 NE station in 2012 ( $\approx 6.5 \mathrm{~km}$ SW of site), the Casa Grande 1.8 NE station in 2013 ( $\approx 7 \mathrm{~km} \mathrm{SW}$ of site), and the Casa Grande 6.5 NNW station in 2014-2019 ( 10 km NNW of site). For each year, I summed daily rainfall to obtain two measures: (a) total rainfall for January-June, and (b) a measure that separated rainfall into two periods, January-March (early rainfall) and April-June (late rainfall).

I assessed effect of rainfall on recruitment using discriminant analysis (SPSS, 1990). Recruitment was a binomial dependent variable (recruitment or no recruitment) and rainfall was the independent variable. The two rainfall variables, total rainfall and early plus late rainfall, were assessed in separate runs of the discriminant analysis. The discriminant analysis developed predictive discriminant functions for each value of recruitment, which was applied to all years during the same execution of the model. The model used a priori classification, and prior probabilities were computed from group sizes. Discriminant analysis also can be used to classify unknowns. To this end, I determined probability of recruitment in an average year by including long-term mean rainfall at the Casa Grande weather station for 1981-2009 and for the period of record (1898-2009) (http://www.wrcc.dri.edu/cgi-bin/cliMAIN.pl?az1306).

\section{3 | RESULTS}

\subsection{Effect of moisture on survival and condition of single queens in the laboratory}

Moisture level was positively associated with survival, measures of condition, and brood production for single queens. Queen survival was significantly higher in the highest moisture treatments (10 and $15 \mathrm{ml}$ water) (logistic regression: $\chi^{2} \geq 31.5, n=270$ queens, $p<0.0001$; Figure 1A), with survival reaching $90 \%$ in the $15 \mathrm{ml}$ treatment. Queen wet mass $(\mathrm{mg})$ did not vary across the three moisture levels (no queens survived in the $0 \mathrm{ml}$ treatment) (one-way ANOVA, $F_{2,83}=1.2, p>0.29$; Figure 1B). The two constituent parts of wet mass, water mass and dry mass, displayed converse patterns. Water mass varied by treatment (one-way ANOVA, $F_{2,83}=4.0, p<0.03$ ), and was significantly lower for queens in the $5 \mathrm{ml}$ than in the $10 \mathrm{ml}$ and $15 \mathrm{ml}$ treatments (Duncan's multiple range test, $p<0.05$; Figure $1 C)$. Dry mass did not vary by treatment $\left(F_{2,83}=2.6, p=0.08\right)$, but Duncan's multiple range test was significant and showed that queens in the $5 \mathrm{ml}$ treatment were heavier than those in the $10 \mathrm{ml}$ and $15 \mathrm{ml}$ treatments (Figure 1D). Total number of brood (workers, pupae, and larvae) also varied by moisture level (one-way ANOVA, $F_{2,85}=4.6, p<0.014$ ), with the fewest brood produced in the $5 \mathrm{ml}$ treatment (Duncan's multiple range test, $p<0.05$; Figure 1E).

\subsection{Effect of moisture and queen number in the laboratory}

In the two-way experiment, queen survival was positively influenced by both queen number and water level (Figure 2). Strength of the grouping effect can be assessed across water levels using the maximum Wald chi-square value for comparisons across queen number within each water level. As predicted, grouping had the highest effect on queen survival in the $0 \mathrm{ml}$ treatment, and its effect decreased progressively at higher water levels $\left(\chi_{\text {[maximum] }}^{2} 0 \mathrm{ml}=32.1\right.$, $5 \mathrm{ml}=18.8,10 \mathrm{ml}=7.4$ ). The $0 \mathrm{ml}$ treatment was the only water level in which queen survival increased significantly from 1 to 3 to five queens (Figure 2).

In the two-way ANOVA, water level was a significant effect for all three measures of queen condition (wet mass, water mass, dry mass), whereas queen number was not significant for any of these same measures (Table 1). The interaction term (water level $\times$ queen number) was significant for water mass, but not for wet mass or dry mass (Table 1 ). In post hoc tests for water level, wet mass at the end of the experiment was higher in the $10 \mathrm{ml}$ treatment than in the 0 or $5 \mathrm{ml}$ treatments (Duncan's multiple range test, $p<0.05$ ), water mass increased progressively from the 0 to 5 to $10 \mathrm{ml}$ treatments $(p<0.05)$, and dry mass was significantly higher in the $0 \mathrm{ml}$ water level than in the 5 and 
FIGURE 1 Effect of water level on: (A) queen survival, (B) queen wet mass, (C) queen water mass, (D) queen dry mass, and $(E)$ number of brood (larvae, pupae, and workers) produced by single queens of the seed-harvester ant Veromessor pergandei. Values are means $+1 S E$. Within each panel, significant differences across moisture levels are indicated by the letters $a-b$ : $a>b$. Groupings are based on (A) a Wald chi-square statistic (see text) or (B-E) a one-way ANOVA followed by Duncan's multiple range test. Note that the one-way ANOVA in panel D was not significant ( $p=0.08$ ), while Duncan's multiple range test was significant $(p<0.05)$. Initial sample size for each treatment is given in panel $A$; number of queens that survived to the end of the experiment (panels $B-E$ ) is given in panel B. ND = no data as no queens survived this treatment
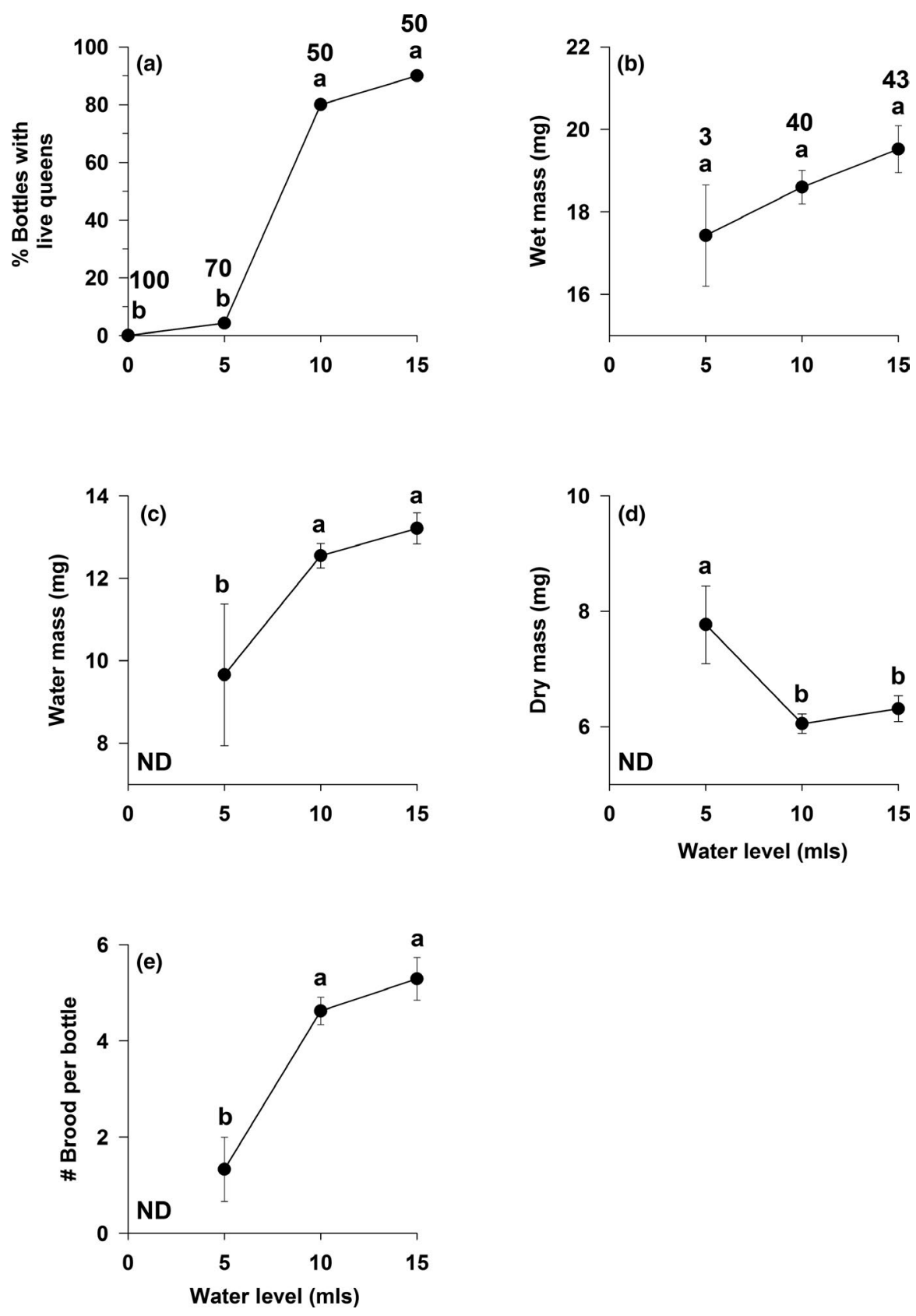

$10 \mathrm{ml}$ treatments $(p<0.05)$, presumably because queens in the latter two treatments invested more mass to produce brood (see Figures 1 and 2). The one-way ANOVA displayed a similar pattern in that wet mass and water mass were consistently higher for the $10 \mathrm{ml}$ treatment (Figure $3 \mathrm{~A}, \mathrm{~B}$ ), whereas dry mass was consistently higher in the $0 \mathrm{ml}$ treatment (Figure $3 C$ ). All three variables displayed an interaction for three and five queens at the 10 and $15 \mathrm{ml}$ treatments.

\section{3 | Growth of single queen colonies in the laboratory}

Single queens produced their first minim workers after an average of 34 days at $30^{\circ} \mathrm{C}$, and they produced up to 25 minim workers without food. After 90 days, colony size increased to an average of $117.0 \pm 14.0$ total brood $(52.8 \pm 6.2$ workers; $64.3 \pm 8.3$ larvae and pupae, $n=20$ queens); the largest colony contained 245 brood (102 workers, 143 larvae and pupae).

\section{4 | Desiccation of founding queens in the field}

Wet mass and water mass varied in a similar pattern across the four groupings of queens. For both measures, the three groups of alate queens collected from their natal nest (field-weighed on 19 Feb, field-weighed on 1 March, hydrated) were significantly heavier than foundress queens (one-way ANOVA, $F_{3,160 \text { [wet mass] }}=30.0, p<0.001$; $F_{3,160 \text { [water mass] }}=67.6, p<0.001$; Duncan's multiple range test, 


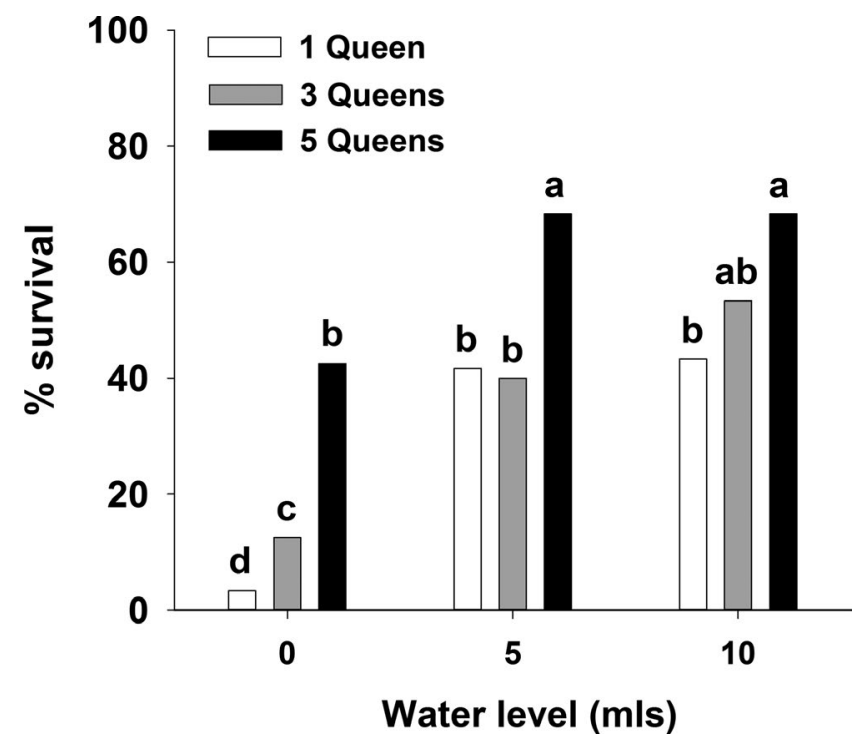

FIGURE 2 Percent survival for queens of the seed-harvester ant Veromessor pergandei in the two-factor bottle experiment (three queen numbers by three water levels). Significant differences across treatment cells are indicated by the letters $a-d: a>b>c>d$. Groupings are based on the Wald chi-square statistic (see text). Sample size per treatment cell; $n=120$ queens for 0 and $5 \mathrm{mls}$ water, $n=60$ queens for $10 \mathrm{mls}$ water

$p<0.001$; Figure 4A,B). Dry mass also varied across the four groupings $\left(F_{3,160 \text { [dry mass] }}=6.1, p=0.001\right)$, and was lowest for foundress queens ( $p<0.05$; Figure 4C). Overall, wet mass of foundress queens averaged $5.62 \mathrm{mg}(14.4 \%)$ less than that of alate queens. The two components of wet mass, water mass and dry mass, accounted for $4.55 \mathrm{mg}(81.0 \%)$ and $1.07 \mathrm{mg}(19.0 \%)$ of the lower founding queen mass, respectively. The $4.55 \mathrm{mg}$ of water equated to $23.8 \%$ of the water mass of alate queens.

In the dehydration experiment, alate queens lost an average of $8.49 \pm 0.17 \mathrm{mg}$ of their body water at the point of mortality, which equated to $41.9 \pm 0.5 \%$ of their hydrated water mass. This percentage was not correlated with initial queen wet mass (linear regression, $p>0.50$ ). However, amount of water lost at the point of mortality was correlated with initial wet mass (linear regression: $\left.Y=0.25 x-1.47, F_{1,36}=31.4, p<0.001, R^{2}=0.47\right)$, indicating that larger queens may better withstand desiccation.

These data can be extrapolated to the field-collected foundress queens. Over the 12 days from their mating flight to excavation, fieldweighed foundress queens lost approximately 53.5\% (4.55/8.49 mg) of the water that can be lost prior to mortality. Assuming a linear rate of water loss (see Johnson et al., 2011), founding queens of V. pergandei can survive desiccating field conditions for approximately 22.4 days.

\subsection{Rainfall and recruitment in the field}

Rainfall was a significant predictor for recruitment of new colonies over the 20 years of field data for both total rainfall (Wilks' $\lambda=0.54$, Chi-square $_{1 d f}=10.7, p=0.001$; Box's $M$ test: $F_{1,228 d f}=0.37$, $p=0.54$ ) and for early and late rainfall (Wilks' $\lambda=0.52$, Chi-square test $_{2 d f}=11.1, p=0.004$; Box's $M$ test: $F_{3,382 d f}=1.62, p=0.18$ ). The positive standardized canonical discriminant function coefficients for total rainfall (1.000) and for early and late rainfall $(0.777$ and 0.645 ) indicated that rainfall positively affected recruitment for both variables; that is, increased rainfall increases recruitment. The similar coefficients for early and late rainfall indicated that both periods had a similar effect on recruitment. Both early and late rainfall were significant in the stepwise discriminant analysis, and both variables had a tolerance of 1.0 , indicating no overlap in the proportion of variance accounted for by the other variable. The robust nature of the discriminant model was evidenced by the high posterior probability for correctly predicting recruitment outcome $(>0.90)$ in 14 of the 20 years for both total and for early and late rainfall (Table 2).

For total rainfall, the discriminant model correctly predicted recruitment outcome in 17 of 20 years (85.0\%), with the two years in which the model correctly predicted recruitment $(1992,2005)$ receiving the highest total rainfall $(>74.0 \mathrm{~mm}$ above the longterm mean for both years) (Table 2). For early plus late rainfall, the

\begin{tabular}{|c|c|c|c|c|c|c|c|}
\hline \multirow[b]{2}{*}{ Source } & \multirow[b]{2}{*}{$d f$} & \multicolumn{2}{|c|}{ Wet mass. } & \multicolumn{2}{|c|}{ Water mass. } & \multicolumn{2}{|c|}{ Dry mass. } \\
\hline & & $F$ & $p$ & $F$ & $p$ & $F$ & $p$ \\
\hline Corrected model & 8 & 8.5 & $<0.001$ & 20.8 & $<0.001$ & 2.5 & 0.013 \\
\hline Moisture level & 2 & 24.2 & $<0.001$ & 58.3 & $<0.001$ & 3.2 & 0.044 \\
\hline Queen number & 2 & 1.3 & 0.26 & 0.9 & 0.42 & 2.1 & 0.13 \\
\hline $\begin{array}{l}\text { Queen number } \times \text { moisture } \\
\text { level }\end{array}$ & 4 & 2.3 & 0.064 & 5.9 & $<0.001$ & 0.3 & 0.9 \\
\hline Error & 260 & & & & & & \\
\hline Total & 269 & & & & & & \\
\hline$R^{2}$ & & 0.21 & & 0.39 & & 0.07 & \\
\hline
\end{tabular}

TABLE 1 Results of two-way ANOVA for the effect of water level and queen number (independent variables) on wet mass $(\mathrm{mg})$, water mass $(\mathrm{mg})$, and dry mass (mg) (dependent variables) for queens of Veromessor pergandei in the bottle experiment (see text)

Note: Analyses included only bottles in which $\geq 2$ and $\geq 4$ queens survived in the 3 and 5 queen bottles, respectively. A separate two-way ANOVA was run for each dependent variable (see also Figure 3). Degrees of freedom (df), $F$, and $p$ values are included. Significant $p$ values are in bold font. 

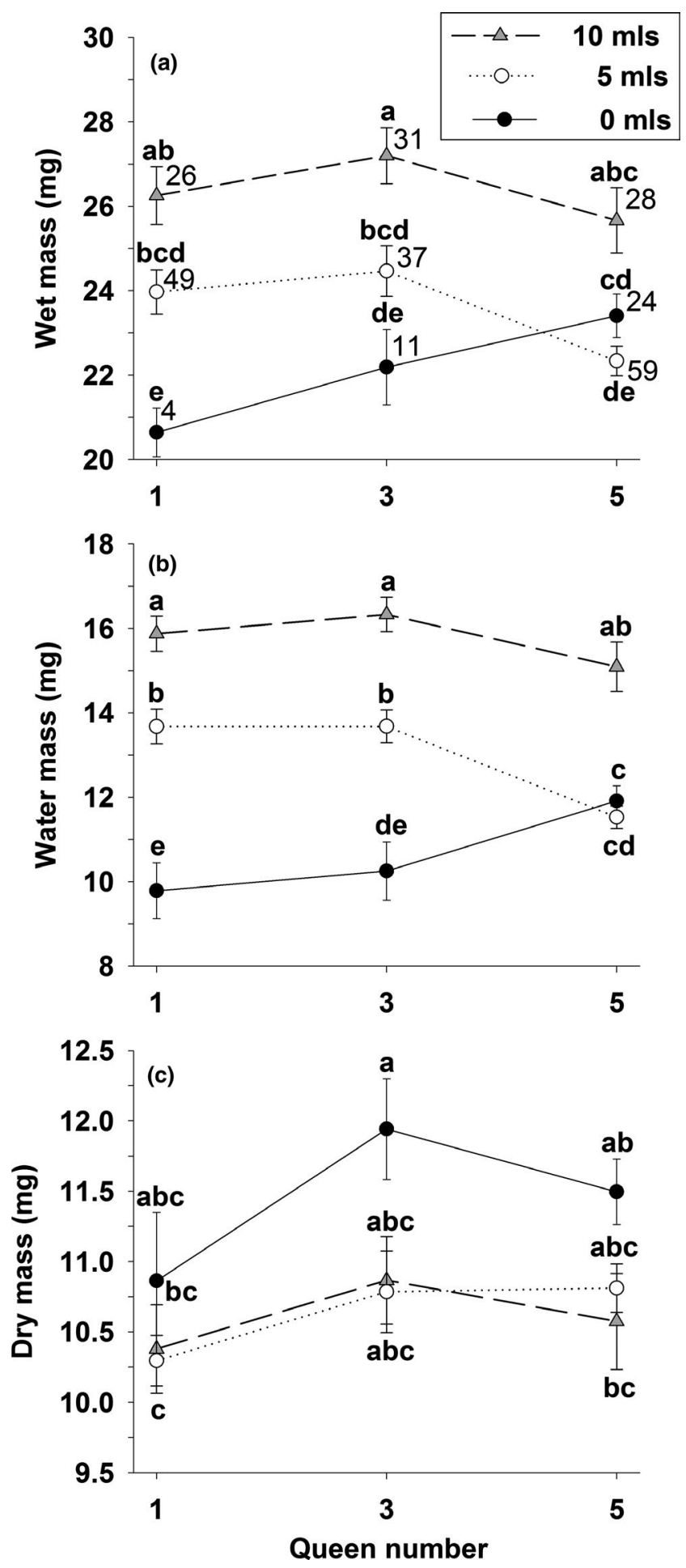

FIGURE 3 Effect of number and water level on: (A) wet mass, (B), water mass, and (C) dry mass for queens of the seed-harvester ant Veromessor pergandei that survived in the two-factor (queen number $\times$ water level) bottle experiment (see also Table 1). Values are means +1 SE. Significant differences across treatment cells are indicated by the letters a-e:

$a>b>c>d>$ e. Groupings are based on a one-way ANOVA followed by Duncan's multiple range test. Panel A gives sample size for treatment cells in all panels. Data include only bottles in which $>2$ or $>4$ queens survived in the 3 and 5 queen bottles, respectively (a)

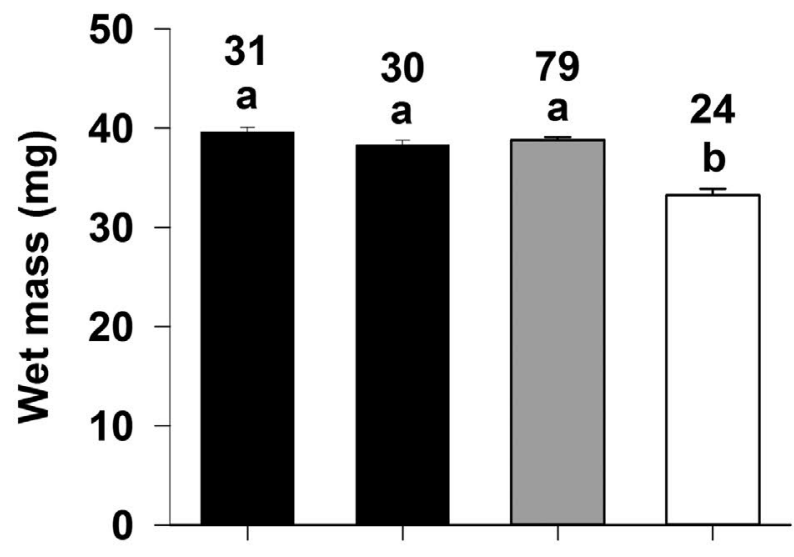

(b)

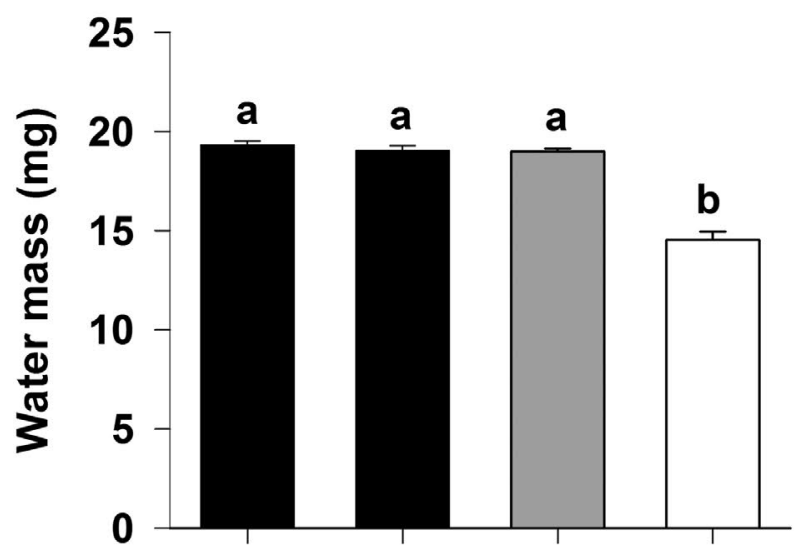

(c)

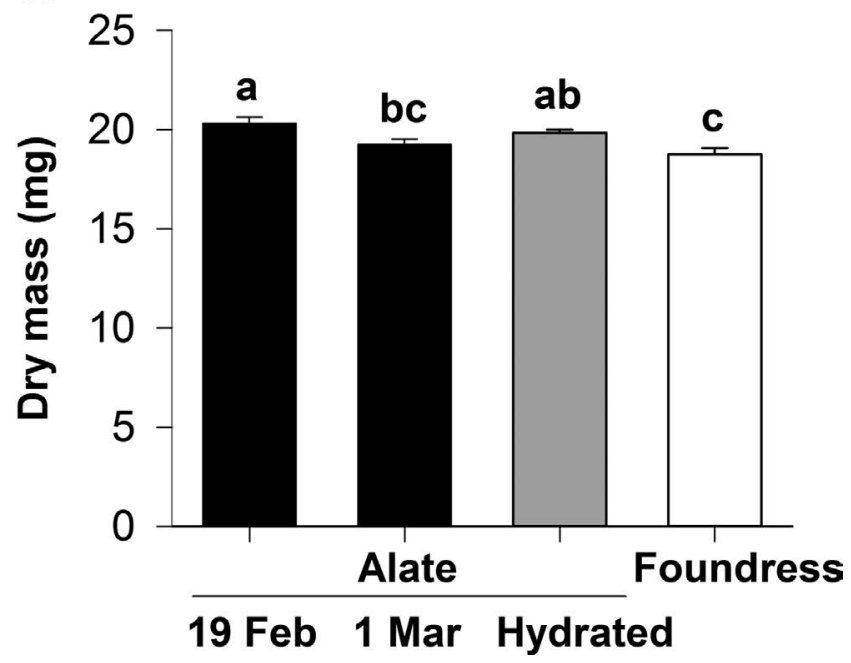

FIGURE 4 Effect of stage on: (A) queen wet mass, (B) queen water mass, and $(C)$ queen dry mass for the seed-harvester ant Veromessor pergandei. = = alate queens, $=$ = hydrated alate queens, and $\square=$ two-week-old founding queens. Values are means $+1 S E$. Significant differences among the four groups are indicated by the letters $\mathrm{a}-\mathrm{c}$ : $\mathrm{a}>\mathrm{b}>\mathrm{c}$. Groupings are based on a one-way ANOVA followed by Duncan's multiple range test. Sample size is given in the top of panel A 


\begin{tabular}{|c|c|c|c|c|}
\hline Year & $\begin{array}{l}\text { Total rainfall } \\
(\mathrm{mm})\end{array}$ & $\begin{array}{l}\text { Early rainfall } \\
(\mathrm{mm})\end{array}$ & $\begin{array}{l}\text { Late rainfall } \\
(\mathrm{mm})\end{array}$ & $\begin{array}{l}\text { Recruitment/posterior } \\
\text { probability }\end{array}$ \\
\hline 1991 & +31.8 & +41.7 & -9.9 & NO $(0.824 ; 0.901)$ \\
\hline 1992 & +150.1 & +97.8 & +52.3 & YES (0.992; 0.998) \\
\hline 1993 & +44.2 & +60.2 & -16.0 & NO (0.706; 0.870) \\
\hline 1994 & -3.1 & -1.8 & -1.3 & NO (0.968; 0.970) \\
\hline 1995 & +6.3 & +18.0 & -11.7 & NO (0.948; 0.970) \\
\hline 1996 & -50.9 & -35.6 & -15.3 & NO (0.997; 0.998) \\
\hline 1997 & -33.8 & -33.3 & -0.5 & NO $(0.994 ; 0.992)$ \\
\hline \multirow[t]{2}{*}{1998} & \multirow[t]{2}{*}{+70.5} & \multirow[t]{2}{*}{+81.0} & \multirow[t]{2}{*}{-10.5} & YES (0.630) \\
\hline & & & & $\mathrm{NO}(0.602)$ \\
\hline 1999 & -49.5 & -58.9 & +9.4 & NO $(0.997 ; 0.994)$ \\
\hline 2000 & -19.9 & -6.1 & -13.8 & NO $(0.987 ; 0.992)$ \\
\hline \multirow[t]{2}{*}{2001} & \multirow[t]{2}{*}{+60.2} & \multirow[t]{2}{*}{+35.6} & \multirow[t]{2}{*}{+24.6} & NO (0.506) \\
\hline & & & & YES (0.657) \\
\hline 2005 & +74.1 & +72.4 & +1.7 & YES $(0.673 ; 0.572)$ \\
\hline 2012 & -30.1 & -24.0 & -6.1 & NO (0.992; 0.993) \\
\hline 2013 & 0.0 & +11.2 & -11.2 & NO $(0.962 ; 0.977)$ \\
\hline 2014 & -60.0 & -43.2 & -16.8 & NO (0.998; 0.999) \\
\hline 2015 & +22.9 & -8.1 & +31.0 & NO (0.883; 0.694) \\
\hline 2016 & -2.6 & -9.4 & +6.8 & NO $(0.967 ; 0.956)$ \\
\hline 2017 & -32.6 & -17.6 & -15.0 & NO (0.993; 0.996) \\
\hline 2018 & -53.2 & -41.2 & -12.0 & NO (0.998; 0.998) \\
\hline 2019 & +35.8 & +47.6 & -11.8 & NO (0.790; 0.891) \\
\hline $\begin{array}{r}1981- \\
2009\end{array}$ & 0.0 & 0.0 & 0.0 & NO $(0.962 ; 0.963)$ \\
\hline $\begin{array}{r}1898- \\
2009\end{array}$ & 0.0 & 0.0 & 0.0 & NO $(0.974 ; 0.976)$ \\
\hline
\end{tabular}

TABLE 2 Deviation from mean total rainfall (January-June) and early (JanuaryMarch) plus late rainfall (April-June) (see text)

Note: Deviation $(\mathrm{mm})$ was calculated as the difference from the 1981-2009 mean rainfall from the weather station nearest the field site (Jan-Mar $=64.0 \mathrm{~mm}$; Apr-June $=16.8 \mathrm{~mm}$ ). Lines in bold font are years in which recruitment by Veromessor pergandei was observed; lines in normal font are years in which recruitment was not observed. The right column gives the discriminant casewise prediction (recruitment or no recruitment) and posterior probability for being in that group (total rainfall; early and late rainfall). Years with casewise predictions on two lines $(1998,2001)$ are those in which the model predicted differed recruitment outcomes for total rainfall and for early and late rainfall (total in first line; early and late on second line). The bottom two lines give predicted recruitment probabilities for the last 30 years (1981-2009) and for the period of record for the weather station nearest the field site (1898-2009).

discriminant model correctly predicted recruitment outcome in 19 of 20 years (Table 2 ), with the three years in which the model correctly predicted recruitment $(1992,2001,2005)$ being the only three years in which both early and late rainfall were higher than the long-term mean (Table 2; Appendix S1). The two years $(1991,1998)$ in which one or both models incorrectly predicted recruitment showed the importance of timing of rainfall. Both years received higher than average total rainfall, with an abundance of early rainfall that included significant rainfall at the end of March, which saturated soils for early parts of the late season (Table 2). Recruitment occurred in 1991 because a significant mid-June rainfall allowed queens to rehydrate and reset their physiological clock, whereas late rainfall in 1998 was limited to early April followed by 11 weeks of drought, and recruitment did not occur.

Importance of high rainfall affecting recruitment also was demonstrated by the discriminant model predicting no recruitment for the two ungrouped periods (1981-2009 and 1898-2009), with a posterior probability $>0.95$ for both total and for early plus late rainfall (Table 2, Appendix S1). Differences between the total rainfall and the early and late rainfall models were caused, in part, by a lack of correlation between early and late rainfall over the years of study $(p>0.20, n=20)$. 


\section{4 | DISCUSSION}

\subsection{Effects of moisture on queen survival and condition}

That water is the most important factor affecting survival and establishment of $V$. pergandei colonies is demonstrated by field data and laboratory experiments. Field data on foundress water balance were collected during 1999, in which early rainfall was far below average (Table 2). During this period, alate queens in their natal nests remained fully hydrated (Figure 4), whereas founding queens desiccated significantly within 2 weeks of initiating their nest because the top $0.5 \mathrm{~m}$ from the soil surface, that is, those areas used by founding queens, remain desiccating except for short intervals following rainfall (Pantastico-Caldas \& Venable, 1993; Reynolds et al., 2004; Young \& Nobel, 1986). Desiccation is undoubtedly the most significant source of queen mortality in most years given that extended dry periods often follow mating flights, and that areas near the soil surface become warmer and drier from early April to late June. That desiccation does not affect mature colonies of V. pergandei is demonstrated in that their alate queens remained hydrated even in an exceptionally dry year. The mechanism by which colonies obtain water is unknown, but incipient colonies likely experience moisture limitation through at least the first year, until the nest is deep enough and/ or sufficient workers are present to buffer environmental harshness and access water as do mature colonies. Colonies of V. pergandei also produce significantly fewer sexual reproductives in dry than in wet years, providing an additional mechanism to limit recruitment in drier years (Cahan, 2001b; Ryti \& Case, 1988).

Alternatively, survival, condition, and brood production by single queens of $\mathrm{V}$. pergandei, and survival and condition of pleometrotic queens consistently increased at higher water levels. That moisture commonly affects survival and establishment of desert ants is suggested by similar effects of water level on survival, queen condition, and brood production in two other common desert seed-harvester ants (Pogonomyrmex barbatus, P. rugosus) (Johnson, 1998). An additional parallel between the two studies was that queen dry mass decreased at higher moisture levels, reflecting the energetic cost of rearing more workers and brood.

\section{2 | Pleometrosis and colony survival in V. pergandei}

Both higher water levels and increased queen number enhanced queen survival in the two-factor bottle experiment. That queen survival was most enhanced in grouped compared to solitary queens in the driest treatment supports the desiccation resistance hypothesis (Figure 2). However, this result contrasted with the main effects of the two-way ANOVA, which indicated water level was a significant effect for all three queen condition variables (wet mass, water mass, dry mass), whereas queen number was not significant for any of these variables (Table 1). These results parallel those of a similar experiment with groups of one and three V. pergandei queens in which grouping increased survival in the driest treatment, but had no effect at higher water levels. Queen condition (proportional water content) and number of brood produced (larvae, pupae, workers) also increased with moisture level, but queen number was not significant (Cahan, 1999).

The interaction term between moisture level and queen number was significant in both studies, indicating that water mass of solitary queens was lower than that of grouped queens at low moisture levels and that these differences disappeared at higher moisture levels (Figure 3).

The mechanism by which queen grouping enhances water balance under desiccating conditions is unknown. Grouping decreases water loss in insects by decreasing surface area and/or increasing local humidity, and the advantages generally increase with group size (Klok \& Chown, 1999; Rasa, 1997). Queens also place their brood in one aggregate pile, which could decrease water loss by decreasing surface area such as occurs for egg masses of butterflies (Clark \& Faeth, 1998), and the benefit would likely increase with number of brood, that is, number of queens. Lastly, strongly desiccating conditions probably result in the queens cannibalizing other queens or brood to regain moisture and/or nutrition (see Cahan, 1999; Tschinkel, 1993).

These results support the desiccation resistance hypothesis for $V$. pergandei in the narrow sense because grouping benefited both survival and water balance of queens, but only under desiccating conditions (see also Cahan, 1999). However, the desiccation resistance hypothesis does not explain the evolution of pleometrosis in the broad sense because these benefits occurred only under the driest conditions, that is, those in which queens have the most negative water balance, produce the fewest brood, and in which recruitment does not occur in the field. It is also doubtful that desiccated queens would experience sufficient rainfall after early April to rehydrate and produce sufficient brood to survive under the increasingly adverse conditions that occur in the ensuing 2-3 months prior to summer rains. That grouped queens also displayed enhanced survival compared to single queens in other studies suggests involvement of mechanisms such as social facilitation rather than desiccation resistance (see also Johnson, 2004; Waloff, 1957).

Overall, these data suggest that pleometrosis in V. pergandei evolved as a mechanism to enhance establishment of new colonies in areas with harsh abiotic (desiccating) conditions, facilitating colonization of habitats in which solitary queens could not persist (see also Avilés, 1999; Sun et al., 2014). Under this scenario, pleometrosis is advantageous only in favorable (wet) years when recruitment occurs, but its effect is negligible in unfavorable (dry) years when recruitment would not occur for single or pleometrotic queens (see also Raczkowski, 2003). This favorable-year hypothesis supports enhanced worker production as the primary advantage of pleometrosis because faster growth facilitates colonies more quickly escaping harsh conditions near the soil surface (see also Raczkowski, 2003). In this sense, queen number is an indirect rather than direct benefit of pleometrosis (Table 1); that is, in favorable (wet) years, one queen 
from a pleometrotic association survives queen reduction, whereas haplometrotic queens produce too few workers to survive even in wet years. That the evolution of pleometrosis is linked to more desiccating conditions also is supported by the transition zone to pleometrosis correlating with reduced precipitation, decreased vegetative biomass, and lower colony density (Cahan, 2001a, 2001b; Cahan et al., 1998).

Ecological constraints such as intense intraspecific competition for space or other resources usually are presumed to select for grouping/cooperation in taxa that include ants, some other social insects, and birds (Bernasconi \& Strassman, 1999; Brockman, 1997). More recently, it was hypothesized that cooperative breeding in many bird species represents a mechanism to colonize harsh environments (Cockburn \& Russell, 2011; Cornwallis et al., 2017; Jetz \& Rubenstein, 2011; Shen et al., 2017); similar suggestions have been made for pleometrosis in V. pergandei (Cahan, 1999; Pfennig, 1995). This dichotomy suggests that cooperation evolves in benign, stable environments where intraspecific competition is intense, as well as in harsh environments where temperatures are hot and interannual variation in rainfall is high (Shen et al., 2017). In this study, V. pergandei queens experience harsh abiotic environments with high interannual variation in rainfall, supporting the hypothesis that pleometrosis evolved to colonize harsh habitats. One measure of environmental harshness is the coefficient of variation in rainfall across years (standard deviation/mean) (see also MacMahon \& Wagner, 1985), which is generally inversely correlated with absolute amount of rainfall. At this site, the average January-June rainfall from 1981-2009 was $80.77 \mathrm{~mm}$ with a coefficient of variation at 0.64 .

That harsh environments favor pleometrosis in V. pergandei can also be examined using predictions of per capita reproductive output derived from insider-outsider conflict theory (Shen et al., 2017). This theory predicts two categories of grouping benefits that relate to benign, stable and harsh environments, respectively-(a) resource defense benefits that derive from groups defending critical resources, and (b) collective action benefits that result from socia cooperation among group members. Per capita reproductive output is predicted to decrease with increasing group size for resource defense benefits, whereas per capita reproductive output increases for collective action benefits. Several pleometrotic ants such as Solenopsis invicta and Lasius niger display decreases in per capita production of minim workers as queen number increases (Bernasconi \& Keller, 1998; Sommer \& Hölldobler, 1995; Tschinkel, 1993), presumably because of intense intraspecific competition. Alternatively, $V$. pergandei inhabits harsh desert habitats and number of minims produced per queen remains the same, at least up to five queens (Rissing \& Pollock, 1991). Thus, observed variation in per capita minim production across ant species also might explain their inhabiting benign, stable versus harsh environments.

In V. pergandei, rapid colony growth is achieved by one queen producing up to 25 first brood workers, which is significantly more than produced by sympatric species of Pogonomyrmex (Johnson, 1998). Subsequent growth leads to some colonies containing $>200$ workers and brood within 3 months (this study; C. Kwapich, unpub. data).
Number of workers produced in the first brood increases linearly with queen number (Rissing \& Pollock, 1991; this study), suggesting that pleometrotic colonies can contain $>1,000$ workers within several months. Indeed, field colonies initiated in March sometimes contain several hundred workers by the time of the census for new colonies (late August to late November) (R.A. Johnson, pers. obs.), such that these colonies had survived the driest and hottest months of the year and were entering the more moderate fall and winter seasons, as well as beginning the ergonomic (growth) phase in which survival rate increases dramatically (Cole, 2009).

The several other proximate hypotheses suggested to explain the evolution of pleometrosis in V. pergandei (see introduction) likely can be discounted. The brood raiding and foraging success hypotheses both predict that the advantage of pleometrosis results from colonies containing more workers. Brood raiding is viewed as a means to gain a competitive advantage in inter-colony competition (Bernasconi \& Strassman, 1999; Rissing \& Pollock, 1987, 1991; Tschinkel, 1992), and it likely functions similarly for V. pergandei, except that the advantages would occur only during favorable (wet) years when recruitment occurs. This hypothesis was criticized by Brown (2000) because brood raiding between incipient colonies had not been observed in the field (see also Pfennig, 1995), but recent observations document brood raiding in the field (Raczkowski, 2003; R.A. Johnson, pers. obs.). Moreover, I propose that brood raiding increases colony size and thus functions in a manner similar to pleometrosis, except that workers are added from neighboring colonies rather than from workers produced by additional queens. The foraging success hypothesis (Brown, 2000) predicts that the additional workers in pleometrotic colonies increase foraging success and hence colony survival and growth. I discount this hypothesis because of the high energetic gain from harvesting seeds, which is more than 100 times the energy cost per trip (Weier \& Feener, 1995), and because foraging success would already be high given that recruitment occurs only in favorable (wet) years when production and availability of annual seeds are highest (Beatley, 1974; Rosenzweig, 1968).

Pfennig (1995) also suggested that pleometrosis might result from newly mated queens needing to quickly obtain cover underground in their incipient nest so as to decrease desiccation and exposure to predators. Mated queens undoubtedly lose water before entering a nest, but this is an ephemeral effect (1-2 hr) that would exert weak selection pressure given the low water loss rate and high desiccation tolerance exhibited by $V$. pergandei queens (Johnson, 2000d; Johnson et al., 2011; this study), combined with the fact that mating flights occur during cooler months, that is, February-March. Likewise, quickly entering a nest does not preclude predation because centipedes and other predators commonly invade incipient nests and kill all queens (C. Kwapich, pers. comm.).

Two field studies have examined pleometrosis in V. pergandei with contradictory results. Pfennig (1995) suggested that interference competition among incipient colonies does not select for pleometrosis because: (a) there was no difference in survival or longevity for one versus two queen colonies, (b) foundresses initiated colonies near adult colonies, and (c) number of queens in incipient colonies 
increased with distance from adult colonies. Alternatively, at the same site Raczkowski (2003) found higher survival and greater longevity for three queen compared to one queen colonies, and that distance to a mature colony did not affect survival or longevity.

Both field studies demonstrate that very low survival in the short and especially longer term requires experiments that use large sample sizes (see also Cole \& Wiernasz, 2002) in multiple years (including wet years) and/or manipulate soil moisture. Note however that experiments that manipulate soil moisture often fail because locally wet soils attract fire ants (Solenopsis xyloni) that kill the foundresses. Another caveat is that pleometrotic colonies of V. pergandei regularly contain 3-7 or more queens (Cahan et al., 1998; Pollock \& Rissing, 1985), such that both field experiments used few queens compared to the number found in typical associations.

Pleometrosis undoubtedly is a derived trait in V. pergandei, especially given that queens are haplometrotic throughout a large portion of the species range (Cahan, 1999; Helms \& Helms Cahan, 2012; Johnson, 2000b). The first step in the evolution of pleometrosis necessitates that non-aggressive alate queens (unmated alate queens in their natal nest) maintain their non-aggressive behavior after mating, rather than becoming aggressive as occurs for species in which queens are haplometrotic. Thus, changes in gene expression and/ or production of neurochemicals that increase aggression cannot occur (Helmkampf et al., 2016; Koyama et al., 2015; Muscedere et al., 2016; Ohkawara \& Aonuma, 2016). If this same non-aggressive behavior continues after minim workers emerge, then queens would remain cooperative, leading to primary polygyny. Alternatively, queen reduction after minim workers emerge requires a change in gene expression and/or production of neurochemicals that increase aggression.

\section{3 | Episodic recruitment}

Water plays a critical role for foundress survival and brood production in V. pergandei given that colony recruitment occurs in only favorable, wet years. This pattern parallels that for many desert plants that exhibit episodic recruitment during years of high summer rainfall (Johnson, 2006; Johnson et al., 1993; Jordan \& Nobel, 1979, 1981; Steenbergh \& Lowe, 1969; Winkler et al., 2018), but this is the first case in which recruitment of a desert ant has been linked directly to rainfall.

Quantity and timing of rainfall affect recruitment of new colonies because recruitment only occurs in years in which both early and late rainfall well exceed the long-term mean. Lack of regular recruitment is also supported by the discriminant analysis showing a near-zero probability of recruitment in an average rainfall year based on the two long-term ungrouped periods that used mean rainfall as a predictor. Early rainfall maintains hydration of foundresses and allows them to produce the maximum number of brood. However, these incipient colonies must survive increasingly hot and arid conditions over the next several months, and above average late rainfall rehydrates the queen and her workers, allowing the colony to reset their physiological "clock" for desiccation tolerance so that they can survive until summer rains (Johnson, 2006). For cactus, time to desiccation increases with plant volume (Jordan \& Nobel, 1981; Nobel, 1988), and a similar study suggests that increased colony size buffers against desiccation induced mortality for ant queens (Kaspari \& Vargo, 1995). A primary difference between plants and desert ants is that the effect of moisture should be more pronounced for ants than plants because seeds can remain dormant for several years until appropriate germination conditions occur, whereas ant queens "germinate" immediately, and hence cannot avoid inclement conditions in any one year (Johnson, 2006).

Overall, more studies need to examine the role of moisture in colony recruitment and desiccation tolerance in V. pergandei and other desert ants (see Menke et al., 2007). For example, the water source for mature colonies is unknown, but colonies remain hydrated given that workers lose water during foraging trips (Lighton et al., 1994), and that alate queens in their natal colony are hydrated under periods of extended drought while foundresses dehydrate under the same conditions (this study). Metabolic water is an unlikely source because it provides relatively little water for workers or queens of sympatric harvester ants (e.g., Pogonomyrmex). Additionally, these ants lack special adaptations to obtain water given that queens lose water even at very high humidities (97.5\%) (Johnson, 1998, 2000a; Lighton \& Feener, 1989). Colony size and depth are likely important in escaping desiccating conditions, but the source of water remains unclear even for mature colonies that extend several meters below the surface (see Tevis, 1958).

Veromessor pergandei also likely will be affected by climate change given that models predict increased aridity (both warmer temperatures and decreased winter-spring rainfall) for deserts of the southwestern United States that are already experiencing an extended drought (Walsh et al., 2014; Williams et al., 2020). Such changes are predicted to affect a greater degree of episodic recruitment in V. pergandei, resulting in fewer age classes and more irregular population dynamics. Changes in aridity might also change microdistribution pattern in V. pergandei and other ants. Veromessor pergandei inhabits locales with more coarse-textured, sandy soils, and it becomes uncommon to absent in finer-textured, clayey soils (Johnson, 1992). This microhabitat limitation appears to relate to water availability because clayey soils hold water more tightly than sandy soils such that the sandy soil has a greater water potential even at a lower water content (Nilsen \& Orcutt, 1996; Reynolds et al., 2004). Thus, infrequent recruitment by V. pergandei in marginal, less sandy soils would be further reduced. Distribution restrictions based on rainfall also parallel desert plants given that some cacti inhabit only sites where rainfall affects seedling establishment in $>10 \%$ of the years (Jordan \& Nobel, 1982). Changes in rainfall patterns might also affect ecological attributes of a species such as queen size. For example, Wiernasz and Cole (2003) found that larger queens of Pogonomyrmex occidentalis were significantly more likely to survive early stages of colony founding than were smaller queens, and such a pattern would likely be enhanced under increasing aridity. This leads to the hypothesis that one explanation for the evolution 
of pleometrosis is that it functions as a behavioral mechanism to increase total queen mass beyond that possible at the level of individual queens. More total reproductive energy facilitates producing more brood, which is imperative for establishing new colonies.

\section{ACKNOWLEDGMENTS}

I thank Christina Kwapich for discussions as well as comments that improved the manuscript. I also thank Jake, Tito, and Pancho for field entertainment and being my long-term field buddies, and who always seemed to have more fun in the field than me. The author has no conflict of interest in regard to this research.

\section{CONFLICT OF INTEREST}

The author declares that he has no competing interests.

\section{AUTHOR CONTRIBUTION}

Robert A. Johnson: Conceptualization (lead); Data curation (lead); Formal analysis (lead); Funding acquisition (lead); Investigation (lead); Methodology (lead); Project administration (lead); Resources (lead); Software (lead); Supervision (lead); Validation (lead); Visualization (lead); Writing - original draft (lead); Writing - review and editing (lead).

\section{ORCID}

Robert A. Johnson (iD https://orcid.org/0000-0002-0242-6385

\section{REFERENCES}

Adams, E. S., \& Tschinkel, W. R. (1995). Effects of foundress number on brood raids and queen survival in the fire ant Solenopsis invicta. Behavioral Ecology and Sociobiology, 37, 233-242. https://doi. org/10.1007/BF00177402

Avilés, L. (1999). Cooperation and non-linear dynamics: An ecological perspective on the evolution of sociality. Evolutionary Ecology Research, 1, 459-477.

Bartz, S. H., \& Hölldobler, B. (1982). Colony founding in Myrmecocystus mimicus Wheeler (Hymenoptera: Formicidae) and the evolution of foundress associations. Behavioral Ecology and Sociobiology, 10, 137147. https://doi.org/10.1007/BF00300174

Beatley, J. C. (1974). Phenological events and their environmental triggers in Mojave Desert ecosystems. Ecology, 55, 856-863. https://doi. org $/ 10.2307 / 1934421$

Bernasconi, G., \& Keller, L. (1998). Phenotype and individual investment in cooperative foundress associations of the fire ant, Solenopsis invicta. Behavioral Ecology, 9, 478-485.

Bernasconi, G., \& Strassman, J. E. (1999). Cooperation among unrelated individuals: The ant foundress case. Trends in Ecology and Evolution, 14, 477-482. https://doi.org/10.1016/S0169-5347(99) 01722-X

Bong, L.-J., Neoh, K.-B., \& Yoshimura, R. (2018). Comparison of water relation in two powderpost beetles relative to body size and ontogenetic and behavioral traits. Environmental Entomology, 47, 990-996. https://doi.org/10.1093/ee/nvy062

Brockman, H. J. (1997). Cooperative breeding in wasps and vertebrates: The role of ecological constraints. In J. C. Chao, \& B. J. Crespi (Eds.), The evolution of social behavior in insects and arachnids (pp. 347-371). Cambridge University Press.

Broly, P., Devigne, L., Deneubourg, J. L., \& Devigne, C. (2014). Effects of group size on aggregation against desiccation in woodlice (Isopoda: Oniscidea). Physiological Entomology, 39, 165-171. https://doi. org/10.1111/phen.12060
Brown, M. J. F. (2000). From the laboratory to the field: The advantage of pleometrotic colony founding. Trends in Ecology and Evolution, 15, 116. https://doi.org/10.1016/S0169-5347(99)01809-1

Bujan, J., Yanoviak, S. P., \& Kaspari, M. (2016). Desiccation resistance in tropical insects: Causes and mechanisms underlying variability in a Panama ant community. Ecology and Evolution, 6, 6282-6291. https:// doi.org/10.1002/ece3.2355

Cahan, S. (1999). Causes and consequences of an abrupt transition in colony founding behavior in the ant Messor pergandei (p. 137). PhD dissertation, Arizona State University, Tempe, Arizona.

Cahan, S. (2001a). Cooperation and conflict in ant foundress associations: Insights from geographical variation. Animal Behaviour, 61 819-825. https://doi.org/10.1006/anbe.2000.1671

Cahan, S. (2001b). Ecological variation across a transition in colony-founding behavior in the ant Messor pergandei. Oecologia, 129, 629-635. https://doi.org/10.1007/s004420100761

Cahan, S., Helms, K. R., \& Rissing, S. W. (1998). An abrupt transition in colony founding behaviour in the ant Messor pergandei. Animal Behaviour, 55, 1583-1594. https://doi.org/10.1006/anbe.1997.0699

Chown, S. L., \& Klok, C. J. (2003). Water balance characteristics respond to changes in body size in sub-Antarctic weevils. Physiological and Biochemical Zoology, 76, 634-643. https://doi.org/10.1086/376919

Clark, B. R., \& Faeth, S. H. (1998). The evolution of egg clustering in butterflies: A test of the egg desiccation hypothesis. Evolutionary Ecology, 12, 543-552. https://doi.org/10.1023/A:1006504725592

Cockburn, A., \& Russell, A. F. (2011). Cooperative breeding: A question of climate? Current Biology, 21, R195-R197. https://doi.org/10.1016/j. cub.2011.01.044

Cole, B. J. (2009). The ecological setting for social evolution: The demography of ant populations. In J. Gadau, \& J. H. Fewell (Eds.), Organization of insect societies: From genome to sociocomplexity (pp. 75-104). Harvard University Press.

Cole, B. J., \& Wiernasz, D. C. (2002). Recruitment limitation and population density in the harvester ant, Pogonomyrmex occidentalis. Ecology, 83 , 1433-1442. https://doi.org/10.1890/0012-9658(2002)083[1433:RLAPDI]2.0.CO;2

Cornwallis, C. K., Botero, C. A., Rubenstein, D. R., Downing, P. A., West, S. A., \& Griffin, A. S. (2017). Cooperation facilitates the colonization of harsh environments. Nature Ecology and Evolution, 1, 0057. https:// doi.org/10.1038/s41559-016-0057

Creighton, W. S. (1950). The ants of North America. Bulletin of the Museum of Comparative Zoology, 104, 1-585.

Creighton, W. S. (1953). New data on the habits of the ants of the genus Veromessor. American Museum Novitates, 1612, 1-18.

Ehleringer, J. R., \& Sandquist, D. R. (2018). A tale of ENSO, PDO, and increasing aridity impacts on drought-deciduous shrubs in the Death Valley region. Oecologia, 187, 879-895. https://doi.org/10.1007/ s00442-018-4200-9

Gibson, A. C., \& Nobel, P. S. (1986). The cactus primer. Harvard University Press.

Hadley, N. F. (1994). Water relations of terrestrial arthropods. Academic Press.

Hagen, R. H., Smith, D. R., \& Rissing, S. W. (1988). Genetic relatedness among co-foundresses of two desert ants, Veromessor pergandei and Acromyrmex versicolor (Hymenoptera: Formicidae). Psyche, 95, 191-201.

Harrison, J. F., Woods, H. A., \& Roberts, S. P. (2012). Ecological and environmental physiology of insects. Oxford University Press.

Helmkampf, M., Mikheyev, A. S., Kang, Y., Fewell, J. H., \& Gadau, J. (2016). Gene expression and variation in social aggression by queens of the harvester ant Pogonomyrmex californicus. Molecular Ecology Notes, 25, 3716-3730.

Helms Cahan, S., \& Helms, K. R. (2012). Relatedness does not explain geographic variation in queen cooperation in the seed-harvester ant Messor pergandei. Insectes Sociaux, 59, 579-585. https://doi. org/10.1007/s00040-012-0255-5 
Helms, K. R., \& Helms Cahan, S. (2012). Large-scale regional variation in cooperation and conflict among queens of the desert ant Messor pergandei. Animal Behaviour, 84, 499-507. https://doi.org/10.1016/j. anbehav.2012.05.019

Hölldobler, B., \& Wilson, E. O. (1990). The ants. Harvard University Press.

Hood, W. G., \& Tschinkel, W. R. (1990). Desiccation resistance in arboreal and terrestrial ants. Physiological Entomology, 15, 23-35. https://doi. org/10.1111/j.1365-3032.1990.tb00489.x

Iknayan, K. J., \& Beissinger, S. R. (2018). Collapse of a desert bird community over the past century driven by climate change. Proceedings of the National Academy of Sciences of the United States of America, 115, 8597-8602. https://doi.org/10.1073/pnas.1805123115

Jerome, C. A., McInnes, D. A., \& Adams, E. S. (1998). Group defense by colony-founding queens in the fire ant Solenopsis invicta. Behavioral Ecology, 9, 301-308.

Jetz, W., \& Rubenstein, D. R. (2011). Environmental uncertainty and the global biogeography of cooperative breeding in birds. Current Biology, 21, 72-78. https://doi.org/10.1016/j.cub.2010.11.075

Johnson, R. A. (1992). Soil texture as an influence on the distribution of the desert seed-harvester ants Pogonomyrmex rugosus and Messor pergandei. Oecologia, 89, 118-124. https://doi.org/10.1007/BF003 19023

Johnson, R. A. (1998). Foundress survival and brood production in the desert seed-harvester ants Pogonomyrmex rugosus and $P$. barbatus (Hymenoptera, Formicidae). Insectes Sociaux, 45, 255-266. https:// doi.org/10.1007/s000400050086

Johnson, R. A. (2000a). Habitat segregation based on soil texture and body size in the seed-harvester ants Pogonomyrmex rugosus and P. barbatus. Ecological Entomology, 25, 403-412.

Johnson, R. A. (2000b). Reproductive biology of the seed-harvester ants Messor julianus (Pergande) and Messor pergandei (Mayr) (Hymenoptera: Formicidae) in Baja California, Mexico. Journal of Hymenoptera Research, 9, 377-384.

Johnson, R. A. (2000c). Seed-harvester ants (Hymenoptera: Formicidae) of North America: An overview of ecology and biogeography. Sociobiology, 36, 89-122.

Johnson, R. A. (2000d). Water loss in desert ants: Caste variation and the effect of cuticle abrasion. Physiological Entomology, 25, 48-53. https://doi.org/10.1046/j.1365-3032.2000.00170.x

Johnson, R. A. (2004). Colony founding by pleometrosis in the semi-claustral seed-harvester ant Pogonomyrmex californicus (Hymenoptera: Formicidae). Animal Behaviour, 68, 1189-1200. https://doi. org/10.1016/j.anbehav.2003.11.021

Johnson, R. A. (2006). Biogeographical parallels between plants and ants in North American deserts (Hymenoptera: Formicidae; Spermophyta). Myrmecologische Nachrichten, 8, 209-218.

Johnson, R. A., Baker, M. A., Pinkava, D. J., \& Ruffner, G. A. (1993). Seedling establishment, mortality, growth, and flower production in acuña cactus, Echinomastus erectocentrus var. acunensis. In R. Sivinski, \& K. Lightfoot (Eds.), Proceedings of the Southwestern Rare and Endangered Plant Conference (pp. 170-180). Santa Fe, New Mexico.

Johnson, R. A., Kaiser, A., Quinlan, M., \& Sharp, W. (2011). Effect of cuticular abrasion and recovery on water loss rates in queens of the desert harvester ant Messor pergandei. Journal of Experimental Biology, 214, 3495-3506. https://doi.org/10.1242/jeb.054304

Jordan, P. W., \& Nobel, P. S. (1979). Infrequent establishment of seedlings of Agave deserti (Agavaceae) in the northwestern Sonoran Desert. American Journal of Botany, 66, 1079-1084. https://doi. org/10.1002/j.1537-2197.1979.tb06325.x

Jordan, P. W., \& Nobel, P. S. (1981). Seedling establishment of Ferocactus acanthodes in relation to drought. Ecology, 62, 901-906. https://doi. org/10.2307/1936987

Jordan, P. W., \& Nobel, P. S. (1982). Height distributions of two species of cacti in relation to rainfall, seedling establishment, and growth. Botanical Gazette, 143, 511-517. https://doi.org/10.1086/337329
Kaspari, M., \& Vargo, E. L. (1995). Colony size as a buffer against seasonality: Bergmann's rule in social insects. American Naturalist, 145, 610-632. https://doi.org/10.1086/285758

Klok, C. J., \& Chown, S. L. (1999). Assessing the benefits of aggregation: Thermal biology and water relations of anomalous Emperor Moth caterpillars. Functional Ecology, 13, 417-427. https://doi. org/10.1046/j.1365-2435.1999.00324.x

Koyama, S., Matsui, S., Satoh, T., \& Sasaki, K. (2015). Octopamine and cooperation: Octopamine regulates the disappearance of cooperative behaviours between genetically unrelated founding queens in the ant. Biology Letters, 11, 20150206. https://doi.org/10.1098/ rsbl.2015.0206

Le Lagadec, M. D., Chown, S. L., \& Scholtz, C. H. (1998). Desiccation resistance and water balance in southern African keratin beetles (Coleoptera, Trogidae): The influence of body size and habitat. Journal of Comparative Physiology, B, 168, 112-122. https://doi.org/10.1007/ s003600050127

Lighton, J. R. B., \& Feener, D. H. Jr (1989). Water-loss rate and cuticular permeability in foragers of the desert ant Pogonomyrmex rugosus. Physiological Zoology, 62, 1232-1256.

Lighton, J. R. B., Quinlan, M. C., \& Feener, D. H. Jr (1994). Is bigger better? Water balance in the polymorphic desert harvester ant Messor pergandei. Physiological Entomology, 19, 325-334. https://doi. org/10.1111/j.1365-3032.1994.tb01059.x

Liu, M., Chan, S.-F., Rubenstein, D. R., Sun, S.-J., Chen, B.-F., \& Shen, S.-F. (2020). Ecological transitions in grouping benefits explain the paradox of environmental quality and sociality. American Naturalist, 195, 818-832. https://doi.org/10.1086/708185

MacMahon, J. A., \& Wagner, F. H. (1985). The Mojave, Sonoran and Chihuahuan Deserts of North America. In M. Evanari, I. Noy-Meir, \& D. W. Goodall (Eds.), Hot deserts and arid shrublands (pp. 105202). .

Menke, S. B., Fisher, R. N., Jetz, W., \& Holway, D. (2007). Biotic and abiotic controls of Argentine ant invasion success at local and landscape scales. Ecology, 88, 3164-3173. https://doi.org/10.1890/07-0122.1

Muscedere, M. L., Helms Cahan, S., Helms, K. R., \& Traniello, J. F. A. (2016). Geographic and life-history variation in ant queen colony founding correlates with brain amine levels. Behavioral Ecology, 27, 271-278. https://doi.org/10.1093/beheco/arv152

Nilsen, E. T., \& Orcutt, D. M. (1996). Physiology of plants under stress. John Wiley and Sons.

Nobel, P. S. (1988). Environmental biology of agaves and cactus. Cambridge University Press.

Noy-Meir, I. (1973). Desert ecosystems: Environment and producers. Annual Review of Ecology and Systematics, 4, 25-51. https://doi. org/10.1146/annurev.es.04.110173.000325

Ode, P. J., \& Rissing, S. W. (2002). Resource abundance and sex allocation by queen and workers in the harvester ant, Messor pergandei. Behavioral Ecology and Sociobiology, 51, 548-556. https://doi. org/10.1007/s00265-002-0462-6

Ohkawara, K., \& Aonuma, H. (2016). Changes in the levels of biogenic amines associated with aggressive behavior of queens in the social parasite Vollenhovia nipponica. Insectes Sociaux, 63, 257-264.

Pantastico-Caldas, M., \& Venable, D. L. (1993). Competition in two species of desert annuals along a topographic gradient. Ecology, 74, 2192-2203. https://doi.org/10.2307/1939573

Pfennig, D. W. (1995). Absence of joint nesting advantage in desert seed harvester ants: Evidence from a field experiment. Animal Behaviour, 49, 567-575. https://doi.org/10.1016/0003-3472(95)80190-1

Plowes, N. J. R., Johnson, R. A., \& Hölldobler, B. (2012). Foraging behavior in the ant genus Messor (Hymenoptera: Formicidae: Myrmicinae). Myrmecological News, 18, 33-49.

Pollock, G. B., \& Rissing, S. W. (1985). Mating season and colony foundation of the seed-harvester ant, Veromessor pergandei. Psyche, 92, 125-134. https://doi.org/10.1155/1985/87410 
Pull, C. D., \& Cremer, S. (2017). Co-founding ant queens prevent disease by performing prophylactic undertaking behaviour. BMC Evolutionary Biology, 17, 219. https://doi.org/10.1186/s12862-017-1062-4

Raczkowski, J. M. (2003). Advantage of pleometrosis in Messor pergandei (Formicidae: Myrmicinae): Evidence from field experiments (p. 42). MS thesis, Ohio State University, Columbus, Ohio.

Rasa, O. A. E. (1997). Aggregation in a desert tenebrionid beetle: A cost/benefit analysis. Ethology, 103, 466-487. https://doi. org/10.1111/j.1439-0310.1997.tb00161.x

Reynolds, J. F., Kemp, P. R., Ogle, K., \& Fernández, R. J. (2004). Modifying the 'pulse-reserve' paradigm for deserts of North America: Precipitation pulses, soil water, and plant responses. Oecologia, 141, 194-210. https://doi.org/10.1007/s00442-004-1524-4

Riddell, E. A., Iknayan, K. J., Wolf, B. O., Sinervo, B., \& Beissinger, S. R. (2019). Cooling requirements fueled the collapse of a desert bird community from climate change. Proceedings of the National Academy of Sciences of the United States of America, 116, 21609-21615. https:// doi.org/10.1073/pnas.1908791116

Rissing, S. W., Johnson, R. A., \& Martin, J. W. (2000). Colony founding behavior of some desert ants: Geographic variation in metrosis. Psyche, 103, 95-101. https://doi.org/10.1155/2000/20135

Rissing, S. W., \& Pollock, G. B. (1986). Social interaction among pleometrotic queens of Veromessor pergandei (Hymenoptera: Formicidae) during colony foundation. Animal Behaviour, 34, 226-233. https:// doi.org/10.1016/0003-3472(86)90027-8

Rissing, S. W., \& Pollock, G. B. (1987). Queen aggression, pleometrotic advantage and brood raiding in the ant Veromessor pergandei (Hymenoptera: Formicidae). Animal Behaviour, 35, 975-981. https:// doi.org/10.1016/S0003-3472(87)80154-9

Rissing, S. W., \& Pollock, G. B. (1989). Behavioral ecology and community organization of desert seed-harvester ants. Journal of Arid Environments, 17, 167-173. https://doi.org/10.1016/S0140-1963(18)30903-0

Rissing, S. W., \& Pollock, G. B. (1991). An experimental analysis of pleometrotic advantage in the desert seed-harvester ant Messor pergandei (Hymenoptera; Formicidae). Insectes Sociaux, 38, 205-211. https://doi.org/10.1007/BF01240970

Rosenzweig, M. L. (1968). Net primary productivity of terrestrial communities: Prediction from climatological data. American Naturalist, 102, 67-74. https://doi.org/10.1086/282523

Ryti, R. T. (1988). Geographic variation in cooperative colony foundation in Veromessor pergandei (Hymenoptera: Formicidae). Pan-Pacific Entomologist, 64, 255-257.

Ryti, R. T., \& Case, T. J. (1988). The regeneration niche of desert ants: Effects of established colonies. Oecologia, 75, 303-306. https://doi. org/10.1007/BF00378614

SAS Institute (1997). SAS/STAT software: Changes and enhancements through release 6.12. SAS Institute Inc.

Scholtz, C. H., \& Caveney, S. (1988). Adaptations in trogid carrion beetles to extremely arid conditions. Journal of Arid Environments, 15, 179191. https://doi.org/10.1016/S0140-1963(18)30991-1

Shen, S.-F., Emlen, S. T., Koenig, W. D., \& Rubenstein, D. R. (2017). The ecology of cooperative breeding behaviour. Ecology Letters, 20, 708720. https://doi.org/10.1111/ele.12774

Sommer, K., \& Hölldobler, B. (1995). Colony founding by queen association and determinants of reduction in queen number in the ant Lasius niger. Animal Behaviour, 50, 287-294. https://doi.org/10.1006/ anbe.1995.0244

SPSS (1990). SPSS reference guide. SPSS Inc.

Steenbergh, W. F., \& Lowe, C. H. (1969). Critical factors during the first years of life of the saguaro (Cereus giganteus) at Saguaro National Monument, Arizona. Ecology, 50, 825-834. https://doi.org/10.2307/1933696

Sun, S.-J., Rubenstein, D. R., Chen, B.-F., Chan, S.-F., Liu, J.-N., Liu, M., Hwang, W., Yang, P.-S., \& Shen, S.-F. (2014). Climate-mediated cooperation promotes niche expansion in burying beetles. eLife, 3 , e02440. https://doi.org/10.7554/eLife.02440
Talbot, M. (1934). Distribution of ant species in the Chicago region with reference to ecological factors and physiological toleration. Ecology, 15, 416-439. https://doi.org/10.2307/1932358

Tejeda, M. T., Arredondo, J., Liedo, P., Pérez-Staples, D., Ramos-Morales, P., \& Díaz-Fleischer, F. (2016). Reasons for success: Rapid evolution for desiccation resistance and life-history changes in the polyphagous fly Anastrepha ludens. Evolution, 70, 2583-2594.

Tevis, L. Jr (1958). Interrelations between the harvester ant Veromessor pergandei (Mayr) and some desert ephemerals. Ecology, 39, 695-704. https://doi.org/10.2307/1931610

Tschinkel, W. R. (1992). Brood raiding in the fire ant, Solenopsis invicta (Hymenoptera: Formicidae): Laboratory and field observations. Annals of the Entomological Society of America, 85, 638-646. https:// doi.org/10.1093/aesa/85.5.638

Tschinkel, W. R. (1993). Resource allocation, brood production and cannibalism during colony founding in the fire ant, Solenopsis invicta. Behavioral Ecology and Sociobiology, 33, 209-223. https://doi. org/10.1007/BF02027118

Tschinkel, W. R., \& Howard, D. F. (1983). Colony founding by pleometrosis in the fire ant, Solenopsis invicta. Behavioral Ecology and Sociobiology, 12, 103-113. https://doi.org/10.1007/BF00343200

Waloff, N. (1957). The effect of the number of queens of the ant Lasius flavus (Fab.) (Hym., Formicidae) on their survival and on the rate of development of the first brood. Insectes Sociaux, 4, 391-408. https:// doi.org/10.1007/BF02224159

Walsh, J., Wuebbles, D., Hayhoe, K., Kossin, J., Kunkel, K., Stephens, G., Thorne, P., Vose, R., Wehner, M., Willis, J., Anderson, D., Doney, S., Feely, R., Hennon, P., Kharin, V., Knutson, T., Landerer, F., Lenton, T., Kennedy, J., \& Somerville, R. (2014). Ch. 2: Our changing climate. In J. M. Melillo, T. C. Richmond, \& G. W. Yohe (Eds.), Climate change impacts in the United States: The third national climate assessment (pp. 19-67). U.S. Global Change Research Program.

Weier, J. A., \& Feener, D. H. Jr (1995). Foraging in the seed-harvester ant genus Pogonomyrmex: Are energy costs important? Behavioral Ecology and Sociobiology, 36, 291-300. https://doi.org/10.1007/s002650050151

Wheeler, J., \& Rissing, S. W. (1975). Natural history of Veromessor pergandei. I. The Nest. Pan-pacific Entomologist, 51, 205-216.

Wiernasz, D. C., \& Cole, B. J. (2003). Queen size mediates queen survival and colony fitness in harvester ants. Evolution, 57, 2179-2183. https://doi.org/10.1111/j.0014-3820.2003.tb00396.x

Williams, A. P., Cook, E. R., Smerdon, J. E., Cook, B. I., Abatzoglou, J. T., Bolles, K., Baek, S. H., Badger, A. M., \& Livneh, B. (2020). Large contribution from anthropogenic warming to an emerging North American megadrought. Science, 368, 314-318. https://doi.org/10.1126/scien ce.aaz9600

Winkler, D. E., Conver, J. L., Huxman, T. E., \& Swann, D. E. (2018). The interaction of drought and habitat explain space-time patterns of establishment in saguaro (Carnegiea gigantea). Ecology, 99, 621-631.

Young, D. R., \& Nobel, P. S. (1986). Predictions of soil-water potentials in the north-western Sonoran Desert. Journal of Ecology, 74, 143-154. https://doi.org/10.2307/2260355

\section{SUPPORTING INFORMATION}

Additional supporting information may be found online in the Supporting Information section.

How to cite this article: Johnson RA. Desiccation limits recruitment in the pleometrotic desert seed-harvester ant Veromessor pergandei. Ecol Evol. 2021;11:294-308. https://doi. org/10.1002/ece3.7039 